\title{
Recommendations of the Group of Experts of the Polish Society of Gynecologists and Obstetricians regarding proceeding with victims of crimes against sexual freedom (01.01.2021)
}

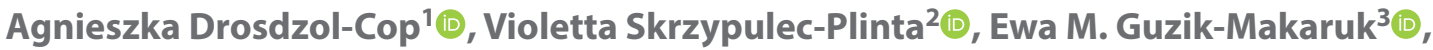 \\ Urszula Drozdowska4 ${ }^{4}$, Dorota Huzarska ${ }^{4} \mathbb{D}$, Anna B. Kluz-Kowal ${ }^{3}$, Jagna Ruminska5 \\ Michal Ciupa ${ }^{6}$, Waldemar Cop $^{7}$, Iwona J. Czech ${ }^{1}$ (i) \\ ${ }^{1}$ Chair and Department of Gynecology, Obstetrics and Oncological Gynecology, Medical University of Silesia, Poland \\ ${ }^{2}$ Department of Woman's Health, School of Health Sciences in Katowice, Medical University of Silesia, Katowice, Poland \\ ${ }^{3}$ University of Bialystok, Poland \\ ${ }^{4}$ Legal Counsel, member of the Chamber of Legal Counsels in Bialystok, Poland \\ 5 Judge of the District Court in Katowice, Poland \\ ${ }^{6}$ Advocate, member of the Bar Association in Katowice, Poland \\ ${ }^{7}$ Prosecutor of the District Prosecutor's Office in Bytom, Poland
}

Ginekologia Polska 2021; 92, 1: 64-79

The recommendations present the current knowledge and procedures, which can be modified and changed in some cases, after careful analysis of a given clinical situation, which in the future may become the basis for their modification and updating.

A gynecologist in his professional practice often encounters victims of crimes against sexual freedom and victims of domestic violence. The list of crimes against sexual freedom is included in the Criminal Code in Chapter XXV and includes the crime of rape (Art. 197), abuse of dependence (Art. 199), sexual intercourse with minors under 15 (Art. 200), and forbidden contact with a minor (Art. 200a), incest (Art. 201) — to name only those crimes that the gynecologist can most clearly reveal. Domestic violence has its own legal definition and such violence is a one-time or repeated deliberate action or omission that violates the rights or personal rights of family members, in particular exposing these people to the risk of losing life, health, violating their dignity, bodily inviolability, freedom, including sexual, causing harm to their physical or mental health, as well as causing suffering and moral harm to people affected by violence. However, family members, also under the statutory definition, should be considered as a spouse, an ascendant, descendant, siblings, related in the same line or degree, a person in an adopted relationship and their spouse, as well as a person who is living together or managing (Art. 2 of the Act of 29 July 2005 on Counteracting
Domestic Violence). A similar definition of the closest person is contained in Art. $115 \$ 11$ of the Criminal Code.

It will always be the doctor's duty to provide medical assistance in the first place, and he or she has the right to focus on this, although some of the medical activities, which will be emphasized each time in the recommendations, should be carried out taking into account the needs of the evidence proceedings in connection with the suspected crime.

Secondly, the doctor should consider whether he or she is under a legal or social obligation to report the suspected crime, and whether there is a basis for exempting him or her from medical confidentiality. According to Art. $304 \S 1$ of the Code of Criminal Procedure, everyone having learned about the commission of an offense prosecuted ex officio has a social obligation to notify the prosecutor or the police about it.

In $\$ 2$ it was decided that state and local government institutions that deal with cases of offenses prosecuted ex officio, are obliged to notify the prosecutor or the police about it and to take the necessary steps until the arrival of the person appointed to prosecute the crime.

\section{THE ROLE OF A DOCTOR IN TAKING CARE OF A VICTIM OF SEXUAL VIOLENCE}

In the first place, the doctor should provide medical care, which consists of:

- recognition and stabilization of emergencies, 
- resolving the issue of the need to aid other patients under his care,

- conducting and documenting a medical interview,

- physical and gynecological examination,

- assessment and treatment of physical injuries,

- collection of material for bacteriological tests,

- prevention of sexually transmitted infections,

- pregnancy prevention counseling,

- scheduling control visits,

- psychotherapeutic assistance,

- preparation of medical documentation, assistance in collecting evidence of a crime after establishing the expectations of law enforcement agencies in this regard (a doctor appointed as an expert),

- notifying the relevant authorities of suspected crime (depending on the specific case).

In case of suspicion of sexual abuse of a girl, the examination should be performed by an obstetrician-gynecologist; in the case of a boy - a pediatric surgeon in cooperation with an obstetrician-gynecologist. If it is suspected the presence of injuries to internal organs that may endanger the life of an injured minor, a consultative pediatric surgeon should be called.

\section{Conducting and documenting a medical interview}

Persons suspected of being victims of sexual abuse should be promptly admitted to the emergency room and placed in a separated room for privacy and intimacy. After the initial assessment of the basic vital functions of the patient (airway patency, cardiovascular capacity) and the exclusion of the presence of injuries of internal organs that may be life-threatening, a detailed medical history should be collected and documented, if possible, which should include the following issues:

- age and personal data of the victim and the alleged perpetrator (link to the victim),

- date, time, place and circumstances of the event,

- date and time of the examination,

- details of the sexual abuse (descriptions of the sexual acts committed, the occurrence of ejaculation, the use of physical violence, weapons, drugs, alcohol consumption, drug use by the victim or perpetrator before the event occurred),

- actions performed by the victim after the incident/attack (change of clothes, bathing, showering, urinating),

- gynecological and obstetric interview (date of the last menstruation, contraception used, current and past sexually transmitted infections (STI), the last voluntary sexual contact, previous operations, pregnancies, births and miscarriages).

\section{General physical examination}

General physical examination should begin with a thorough assessment of the general and emotional state of the victim, assessment of the entire body, with particular emphasis on the area of the lower abdomen, inner and outer surface of the thighs, buttocks and limbs, in order to look for signs related to violence (edema, ecchymosis, skin abrasions, bites, wounds, fractures). All injuries located outside the genitals should also be accurately described on the forensic examination card (character, injury location sketch).

The medico-forensic analysis should be performed within 72 hours of the sexual act; the earlier the examination and sampling takes place, the more likely it is to secure the evidence properly.

Physical examination may take place in the presence of an assistant - another doctor, midwife or nurse, only when it is necessary due to the type of service or with the consent of the patient and in the presence of a relative indicated by the victim (in the case of an adult victim's request), conditions ensuring comfort and intimacy.

Pursuant to Art. $3 \mathrm{sec} .1$ point 2 of the Act on Patient Rights and the Patient's Rights Ombudsman, a close person means a spouse, relative or affinity up to the second degree in a straight line, a statutory representative, a person living together or a person indicated by the patient.

In the case of minors, the examination should be conducted in the presence of a statutory representative or a de facto guardian. Pursuant to the provisions of the Family and Guardianship Code, the legal representative is, in principle, the parent or legal guardian. According to Art. 3 sec. 1 point 1 of the Act on Patient's Rights and the Patient's Rights Ombudsman, actual guardian means a person who, without statutory obligation, takes permanent care of a patient who requires such care due to age, health or mental state.

A minor may ask for a gynecological examination in intimate conditions - without the presence of a statutory representative/actual guardian, which should be recorded in the medical documentation. If the statutory representative/actual guardian does not consent to the examination without his or her presence, this fact should be recorded in the medical documentation and the examination should be carried out in his or her presence.

However, it should be borne in mind that in the event of a suspicion that a minor is a victim of a crime against sexual freedom, the doctor may conduct an examination of this person, if there is neither a statutory representative nor a de facto guardian, or communication with these persons is impossible (e.g. intoxication, state after the use of narcotic drugs and psychotropic substances). The objection of the legal representative or de facto guardian, with the possibility of communicating with them, can be overcome with the consent of the guardianship court. 
Legal regulations regarding obtaining the consent of a patient who is a victim of a crime against sexual freedom or domestic violence to provide health services and examination do not differ from the general principles expressed in art. 15-19 of the Act of November 6, 2006 on patient's rights and the Patient's Rights Ombudsman and in Art. 32-34 of the Act of December 5, 1996 on the professions of doctor and dentist:

- in the case of a minor patient, it is obligatory each time to obtain the consent of his or her statutory representative for the provision of health services to the patient, and if the patient is over 16 years of age - to obtain the consent of this patient. In a situation where such a patient uses his or her right to object to the provision of a health service, despite the consent of the statutory representative or actual guardian, the consent of the guardianship court is required;

- in the absence of a statutory representative, consent may be given by the actual guardian of a minor patient, but only regarding the examination themself;

- in a situation where the patient does not have a statutory representative or it is impossible to contact him, the consent of the guardianship court is required to provide health services;

- exceptions include situations where the patient requires immediate medical attention, and due to his health or age, he or she cannot give his consent and it is not possible to contact his or her legal representative or actual guardian. In this case, examination or providing the patient with another health service without his or her consent is permissible, but such a decision should be consulted with another doctor, if possible, and the circumstances should be noted in the patient's medical records. If the delay caused by the consent procedure would pose a threat to the patient's life, serious injury or serious health impairment, the doctor is obliged to consult another doctor, if possible, of the same specialty, if possible. The doctor immediately notifies the statutory representative, actual guardian or the guardianship court about the performed activities, informing them of the circumstances, and all these conditions must be met jointly - from the conditions determining the patient's situation to the fulfillment of formal conditions;

- consent or objection may be expressed orally or by such behavior of the entitled person, which clearly indicates the will to undergo the activities proposed by the doctor or the lack of such will, only in the case of a surgical procedure or the use of a treatment or diagnostic method that poses an increased risk for the patient, consent to provide health services must be received in writing;
- in each case, before giving consent, the person authorized to express consent has the right to obtain information on his or her health condition, diagnosis, proposed and possible diagnostic and treatment methods, foreseeable consequences of their use or omission, treatment results and prognosis;

- the doctor should take into consideration the minor's opinion and respect the position taken by him or her, considering the degree of his maturity, unless it is contrary to the regulation described above.

\section{Gynecological examination}

Gynecological examination should be the final stage of the physical examination of a minor or adult victim of sexual violence. All genital injuries should be carefully recorded on the victim's examination card (detailed description, sketch of the location). In gynecological examinations, carefully selected gynecological specula should be used, which in selected cases can only be moistened with $0.9 \%$ $\mathrm{NaCl}$ solution. A rectal examination should be performed if anal penetration is suspected or there is evidence of trauma to the area.

In girls, gynecological examination can be performed in the lithotomy position, "frog" position or knee-thoracic position - the most comfortable for the child and allowing the collection of the material. The most common injuries to female genital organs resulting from sexual violence against minor include abrasions to the posterior commissure, labia minora, hymen and the urethral fossa.

During the gynecological examination, a swab should be taken from the vaginal vestibule (girls), vagina and the external os of the cervix (adult patients and sexually active girls) using a properly prepared sterile swab - ensuring constant air access (provided by a forensic technician). Then take a swab around the anus in a similar way.

If vaginal penetration is suspected, collect vaginal discharge or, in its absence, vaginal lavage using a small volume of sterile $0.9 \% \mathrm{NaCl}$ solution (set consisting of a plastic pipette and test tube) and collect a cytological smear from the cervix and cervical canal (set for cytology collection). Laboratory testing of such material can detect motile sperm, other sperm components (acid phosphatase, p30 protein, antigen specific for seminal vesicles) and $A B O$ antigens. Detection of sperm in vaginal discharge confirms sexual contact within the previous few hours (motile sperm can survive up to 8 hours, immobile sperm up to 24 hours). In a cervical smear, mobile sperm can be detected for several days (2-3 days), and motionless sperm up to 17 days after vaginal intercourse.

In the case of sexual abuse against a boy, the male genitalia should be carefully assessed, and the existing injuries 
should be accurately described in the boy's examination card. A swab should also be collected from the external urethra and the anal area using properly prepared sterile swabs with constant air access.

The collection of material evidence in the case of genital-oral contacts consists of taking a swab from the oral cavity (using a properly prepared sterile swab with constant air access) and oral rinses (using a 10\% ethanol solution, which fixes DNA acid and prevents the growth of bacteria) into a sterile container (urine container). It should be emphasized that semen is quickly destroyed by the enzymes of saliva, so it is extremely difficult to determine whether ejaculation has occurred in the oral cavity.

\section{Prevention of sexually transmitted infections}

The risk of having a sexually transmitted infection (STI) as a result of forced sexual contact in the group of sexually active women in the last three months is approximately $14.4 \%$, and among sexually inactive children and girls approximately $4.3 \%$. The frequency of different infections among victims of forced sexual contact varies as follows: $19.5 \%$ - Gardnerella vaginalis, $12.3 \%$ - Trichomonas vaginalis, 6-12\% - Neisseria gonorrhoeae, 4-17\% - Chlamydia trachomatis, 3\% - Treponema pallidum and viral infections (HBV, HCV, HIV) - about $0.5 \%$.

In rape victims, it is recommended to perform diagnostic microbiological tests for gonorrhea and chlamydiosis, if possible. The culture material should be collected from all contact sites (vagina, cervix, anus, pharynx). Additionally, it is recommended to perform diagnostic tests for syphilis and adequate treatment after obtaining the result.

In some adult women/underage girls - victims of sexual abuse, prophylactic antibiotic therapy is recommended, depending on individual indications:

- in the case of N. gonorrhoeae infection - ceftriaxone (250 mg i.m. in a single dose) or cefixime (400 mg in a single dose) or ciprofloxacin (500 $\mathrm{mg}$ in a single dose) or ofloxacin (400 mg in a single dose) or spectomycin ( $2 \mathrm{~g}$ in a single dose). single dose), in children - dosage depending on age and body weight;

- Ch. trachomatis - azithromycin (1 g p.o. in a single dose) or doxycycline (100 mg p.o. every 12 hours for 7 days) - contraindicated in pregnant women, in children - dosage depending on age and body weight;

- T. vaginalis or G. vaginalis - metronidazole (2 g p.o. in a single dose) - in pregnant women only after completing the first trimester, in children - dosing depending on age and weight;

- immunization against hepatitis B - if the victim has not been fully vaccinated before;
- prophylactic treatment of tetanus - unvaccinated women/girls.

Victims of sexual violence should be tested for HIV infection during the first examination and repeated six weeks after the incident. The WHO also recommends that all rape victims should receive prophylactic antiretroviral treatment within 72 hours of the act, including: Zidovudine (300 mg every 12 hours) and Lamivudine ( 150 mg every 12 hours) for 28 days; in children, the dosage depends on age and body weight.

\section{Counseling in the field of pregnancy prevention}

The overall risk of pregnancy following an act of sexual violence is around five percent. The routine procedure during the examination of the victim is to perform a pregnancy test, document the result and determine the date of the last menstruation. Rape victims should be allowed to use emergency contraception, according to individual indications.

\section{Psychological help}

The victims of sexual violence may have symptoms of the acute phase of post-traumatic stress disorder in the form of anger, fear, anxiety, increased tearfulness or lack of expression of emotions. The physician should provide psychological support to the victim of sexual abuse. The ideal solution is the availability and immediate intervention of a clinical psychologist. The tasks of the doctor also include informing the injured person about the possible long-term consequences of sexual abuse (e.g. sleep disorders, mood swings, depression) and indicating the place of psychotherapeutic help.

\section{The issue of notifying the law enforcement agencies and the guardianship court about the suspected crime}

There are regulations in the legal system which require cooperation with judicial authorities in certain situations.

The most important obligation results from Art. 240 of the Penal Code, as failure to comply with it is punishable by a criminal sanction. The obligation of immediate notification under the Act in situations that may be encountered by a doctor applies to the following prohibited acts: murder, unlawful deprivation of liberty, as well as any crime of a terrorist nature. At the same time, it should be emphasized what may be important in practice, that the obligation to notify also applies to the attempted offenses mentioned above and, equally important, also to situations in which, due to insanity or age, the perpetrator of the act will not be held criminally responsible. In such a situation, notification should be made "as soon as possible", which does not 
mean"immediately", but only "without undue delay". Only in a situation where a doctor is already dealing with decease, in the case of a justified suspicion that the cause was a crime, the doctor, as well as other persons appointed to inspect the body, should immediately notify the prosecutor or the nearest police station (Art. 11 par. 8 of the Act of January 31,1959 on cemeteries and burying the dead).

According to Art. 12 of the Act on Counteracting Domestic Violence in the version from 2010, persons who, in connection with the performance of their official or professional duties, suspect that an ex officio criminal offense involving domestic violence has been committed, shall immediately notify the Police or the prosecutor. In this way, the act clearly identifies the addressee of such notification. Therefore, this obligation currently has a wide subjective scope, as it covers persons practicing their profession even outside the employment relationship, and therefore also within the individual medical practices.

This obligation, however, only applies to offenses prosecuted ex officio, which from 27 January 2014 also include the crime of rape (also rape of an adult - Art. 197 of the Penal Code), so far prosecuted under absolute petition. Offenses of violation of bodily inviolability, including minor health detriment, and punishable threats prosecuted under the application procedure are still prosecuted under private prosecution, if these behaviors do not turn into a crime of abuse.

However, according to Art. $304 \S 1$ of the Code of Criminal Procedure (CCP), everyone who learns about the commission of an offense prosecuted ex officio is obliged to notify the prosecutor or the Police about it. Therefore, this obligation is universal and, as it results directly from the act, it is a social obligation, and therefore it has not been sanctioned.

The legislator has shaped this obligation somewhat differently with regard to state and local government institutions which, pursuant to Art. $304 \$ 2$ of the Code of Criminal Procedure, provided that, in connection with their activity, they learn about the commission of an offense prosecuted ex officio, they are obliged to immediately notify the prosecutor or the Police about it. Moreover, in such a situation, these institutions have an additional obligation to take the necessary actions until the arrival of the authority appointed to prosecute crimes or until the authority issues an appropriate order to prevent the obliteration of traces and evidence of the crime. This obligation does not rest with every employee, but only with those persons who are authorized to act on behalf of the institution. A self-government institution is also a medical chamber as an institution of professional self-government.

The obligation to notify may be fulfilled by written or personal notification to any unit of the Police or the pros- ecutor's office, and it may be done even by telephone after making sure that the caller is identified. This fact should be noted in your notes due to the high probability of being a witness in a possible court case.

However, notification of the guardianship court is possible under Art. 572 of the Code of Civil Procedure. This provision stipulates that anyone who is aware of an event justifying the initiation of proceedings ex officio is obliged to notify the guardianship court about it. This obligation rests primarily with registry offices, courts, public prosecutors, notaries, bailiffs, local government and government administration departments, police departments, educational institutions, social welfare workers, and organizations and institutions dealing with the care of children or mentally ill people.

Pursuant to Art. 109 of the Family and Guardianship Code, if the child's welfare is at risk, the guardianship court will issue appropriate orders. The guardianship court may, in particular:

1. oblige the parents and the minor to specific proceedings, in particular to work with a family assistant, carry out other forms of work with the family, refer the minor to a day support facility, specified in the provisions on supporting the family and the foster care system, or refer parents to an institution or a specialist dealing with to family therapy, counseling or providing other appropriate help to the family, while indicating how to control the implementation of issued orders;

2. determine what activities may not be performed by the parents without the consent of the court;

3. submit the parental authority to the constant supervision of a probation officer;

4. refer the minor to an organization or institution established for apprenticeship or to another facility that takes partial custody of children;

5. order the minor to be placed in a foster family, family orphanage or in institutional foster care or temporarily entrust the performance of the function of a foster family to spouses or a person who does not meet the conditions for foster families, in terms of the necessary training, specified in the provisions on supporting the family and foster care system, or order the placement of the minor in a care and treatment institution, a nursing and care institution or a medical rehabilitation facility.

The appropriate court in this case will be the family division of the district court consistent with the child's place of residence.

It is aptly argued in the literature that the society's willingness to cooperate with law enforcement agencies depends on the level of awareness and legal culture of the society, the degree of the sense of the threat of crime and the public opinion on the efficiency of law enforcement 
agencies, the way citizens are treated by these authorities and the role they play in society. The summing up conclusion is also indisputable that the more law enforcement agencies are perceived as acting for the benefit of the citizen and the less they are perceived as an apparatus of repression, the more they can count on citizens' readiness to cooperate.

\section{The issue of the obligation to maintain doctor-patient confidentiality and the notification of a suspected crime}

Each time, when considering notifying law enforcement authorities about a suspected crime, a doctor must first of all determine whether he or she is exempt from the obligation to keep confidential information related to the patient and obtained in connection with the performance of the profession. The doctor is also bound by the doctor-patient confidentiality after the patient's death.

According to Art. 40 sec. 2 of the Act on the Professions of Physician and Dentist the prohibition of disclosing information covered by medical confidentiality shall not apply only when this is provided for in another Acts, or when the medical examination was carried out at the request of authorized persons, on the basis of separate acts, departments and institutions, but then the doctor is obliged to inform only those authorities and institutions about the patient's health. This prohibition does not apply to the doctor also when keeping the secret may pose a threat to the life or health of the patient or other people, or the patient or his legal representative agrees to disclose the secret, after informing about the negative consequences of its disclosure for the patient. This prohibition also does not apply when there is a need to provide the necessary information about the patient to the forensic doctor or when there is a need to provide the necessary information about the patient related to the provision of health services to another doctor or authorized persons participating in the provision of these services.

Statutory regulations that impose an obligation on a physician to disclose, to a certain extent, information covered by medical confidentiality include, for example, Art. 27 of the Act of December 5, 2008 on preventing and combating infections and infectious diseases in humans. However, it is commonly accepted that the obligation to maintain medical secrecy is "stronger" than the obligation to denounce under Art. $304 \S 1$ of the Code of Criminal Procedure due to the above-mentioned universal nature of this obligation. However, the nature of the regulation under Art. 12 of the Act on Counteracting Domestic Violence is debatable, but in this case, in the majority number of situations, the doctor will be released from the obligation of secrecy when he decides that his behavior may pose a threat to the life or health of the patient or other people. It is also argued in the literature that exemption from medical confidentiality may also take place on the basis of the patient's consent in a situation where such consent will only be presumed by the doctor, e.g. in the case of an unconscious rape victim, i.e. in a situation where the doctor believes that the conscious patient would give such consent.

To sum up, a gynecologist, having encountered victims of crimes against sexual freedom and victims of domestic violence in his professional practice, is, beyond all doubts, released from the obligation to keep confidential information related to the patient and obtained in connection with the performance of his profession in any of the following situations:

- specified in art. 240 of the Criminal Code

- when confidentiality may endanger the life or health of the patient or other people

- when the patient or his legal representative consents to the disclosure of the secret, having previously informed about the negative consequences of its disclosure for the patient.

It should be emphasized that in each of the situations described above, disclosure of a secret may only take place to the extent necessary, i.e. to initiate and conduct criminal proceedings.

Violation of medical confidentiality may be associated with professional liability in a medical court (Articles 25-29 of the Code of Medical Ethics), civil liability (infringement of the patient's personal rights), and the most far reaching consequence may be criminal liability (Art. $266 \S 1$ of the Penal Code). Article 266 of the Penal Code provides that anyone who, contrary to the provisions of the Act discloses or uses information which he has become acquainted with in connection with his/her function, work, public, social, economic or scientific activity, is subject to a fine, penalty restriction of liberty or imprisonment for up to two years. The prosecution of this crime takes place at the request of victim.

On the other hand, a public official who discloses to an unauthorized person information classified as "restricted" or "confidential" or information obtained in connection with the performance of official activities, and the disclosure of which may endanger a legally protected interest, shall be subject to imprisonment for up to three years. This offense is prosecuted ex officio.

\section{The issue of appointing a doctor as an ad hoc expert - examination of a patient at the request of law enforcement agencies}

Procedural authorities, accepting a notification of an offense from the victim or gaining reasonable knowledge of a suspected crime, should immediately proceed to the implementation of procedural steps. 
One of the procedural steps is visual inspection (Art. $207 \S 1$ of the Code of Criminal Procedure), carried out only by a procedural authority who may summon an expert (Art. 198 §1 of the Code of Criminal Procedure) or a specialist (Art. $205 \$ 1$ of the Code of Criminal Procedure). This operation cannot be repeated at further stages of the criminal proceedings and therefore should be performed with particular care. The observations made during it will not only guide further proceedings, but above all will verify the preliminary findings.

In cases of rape and other sexual offenses, material evidence is of particular importance as material evidence provide objective knowledge about the facts. In the case of rape crime, the physical contact of the victim with the perpetrator usually leaves specific traces of interaction on their bodies and clothes, e.g. hair, fibers, biological traces (e.g. blood, skin, sperm, vaginal discharge). The victim may also be injured in some way. Their number and severity will depend on the degree of violence used by the attacker, as well as on how much resistance the victim himself or herself resists. It should be emphasized, however, that in a situation where the victim did not resist strongly, or the perpetrator underwent the desired sexual activities or intercourse out of fear of more painful behavior, bodily injuries may be minimal or imperceptible.

Pursuant to Art. $192 \S 1$ of the Code of Criminal Procedure, the victim cannot object to body inspections and examinations when the punishment of the act depends on his or her health condition. Whereas Art. $192 \S 4$ of the Code of Criminal Procedure stipulates that, for evidentiary purposes, every witness may be subjected to a body inspection and a medical or psychological examination, but only with his or her consent.

Due to the multiplicity and variety of events that violate the norms of criminal law, procedural authorities must use the assistance of experts. An expert opinion is requested when the circumstances significant for the resolution of the case requires special knowledge (Art. $193 \S 1$ of the Code of Criminal Procedure). Therefore, an opinion is always needed if the determination of a given circumstance requires special knowledge and it does not matter whether the procedural body has such knowledge itself. The Supreme Court indicates that special knowledge should include all the knowledge and skills that go beyond the average and practical. Undoubtedly, the doctor participating in the body inspection is a person who has special information within the meaning of Art. $193 \S 1$ of the CCP.

At the same time, the Act of 5 December 1996 on the professions of physician and dentist provides within physician's duties issuing medical reports (Art. 2). These judgments can be of different nature, form and purpose. A medical report should be understood as a written or oral statement by a doctor containing conclusions drawn from the stated facts and intended for non-medical institutions. In the legal sense, the submitted written or oral statement of a doctor appointed as an expert is called an expert doctor's opinion or a forensic medical opinion.

The expert is appointed ex officio or at the request of the parties, specifying the scope of his tasks. We can distinguish two types of experts:

- a court expert is a person entered on the list of court experts,

- an ad hoc expert is a person who is not a court expert but, due to his knowledge, is called to perform the activities of an expert.

Pursuant to Art. 195 of the Code of Criminal Procedure, not only an expert witness is obliged to act as an expert witness, but also any person known to have appropriate knowledge in a given field. There is no difference in the treatment and assessment of an expert opinion submitted by a court expert or by another expert appointed in a specific case by a procedural authority.

If activities are performed to the extent necessary (Art. $308 \S 1$ of the Code of Criminal Procedure), it is permissible, if necessary, to conduct an inspection with the participation of an expert. These activities take place before the formal initiation of an investigation. In such a case, the appointment of an expert may also take place in a form dictated by the need to prevent the loss of evidence of the crime, their distortion or destruction. In urgent cases, the appointment of an expert may therefore take place in a form other than a written decision, even e.g. in a telephone conversation, although it must be confirmed in the appropriate form in the further course of the proceedings.

Pursuant to Art. $205 \$ 1$ of the Code of Criminal Procedure, when inspections, interrogations with the use of technical devices enabling this activity to be carried out at a distance, experiment, expertise, keeping things or searching, will require technical activities, in particular, such as: taking measurements, calculations, photos, recording traces, specialists may be called in to participate. A specialist is a person who has special knowledge necessary to perform technical activities (e.g. a forensic technician).

Therefore, if a doctor, acting as an expert, does not have the appropriate equipment to secure the traces of sexual abuse and to properly collect material evidence, he or she should call a forensic technician through the duty officer of the nearest Police unit.

The doctor appointed as an expert is obliged to provide the competent authorities with information about the patient's health, because art. $40 \mathrm{sec}$. 2 point 2 u.z.l.I.d. allows the disclosure of the secret when the examination was carried out at the request of authorized bodies and institutions. 
The expert is entitled to obtain remuneration for the activities performed. In relation to expert doctors, detailed guidelines on the method of calculating remuneration can be found in Annex 1 to the Ordinance of the Minister of Justice of April 24, 2013 on determining the rates of expert remuneration, flat rates and the method of documenting expenses necessary for issuing an opinion in criminal proceedings issued on pursuant to Art. $618 \mathrm{f}$ $\S 5$ of the CCP.

An expert serves as an auxiliary to a judicial authority and therefore is excluded from giving an opinion for the same reasons as a judge, i.e. when doubts as to his impartiality could arise. Persons closest to the parties to the proceedings, or persons who witnessed the act (Art. $196 \S 1$ of the Code of Criminal Procedure) cannot be experts. If the reasons for excluding an expert are revealed, the opinion issued by him does not constitute evidence, and another expert is appointed in place of the excluded expert (Art. $196 \S 1$ of the Code of Criminal Procedure).

The doctor appointed as an expert during the examination of the person should assist the law enforcement authorities in securing the traces of the crime.

A person who unjustifiably evades the performance of an expert's activity may be fined with an ordinal fine of up to PLN 10,000, and in the event of persistent and unjustified evasion, also order arrest (Art. $287 \S 1$ and 2 of the CCP).

The role of the doctor as an expert is extremely important. It enriches the knowledge of the procedural authority about the subject of inspection by communicating the facts detected and revealed thanks to his or her special information. The information obtained from him or her indicates to the procedural authority the need to perform other activities related to the conducted proceedings.

\section{ANNEX 1. DOCUMENTATION NECESSARY FOR FORENSIC EXAMINATION OF THE VICTIM OF SEXUAL ABUSE EXAMINATION OF AN ADULT VICTIM OF SEXUAL ABUSE}

A sexual abuse victim examination and evidence collection kit should contain:

- properly prepared sterile swabs with constant access to air (6-8 pieces)

- plastic pipettes and test tubes (2 pieces)

- cytology collection kit

- basic slides (8-10 pieces)

- a sterile urine container (mouthwash)

- solutions: $100 \mathrm{~mL}$ of $0.9 \% \mathrm{NaCl}$ and $100 \mathrm{~mL}$ of $10 \%$ ethanol

Each sample of the collected material for testing should contain information on the label regarding: the type of material, date and time of collection, identification data of the victim and the person who collected the material. The samples should be stored in a safe place, and when handing them over to the Police, obtain appropriate documentation (material evidence receipt protocol).

\section{ANNEX 2. EXAMINATION CARD OF AN ADULT VICTIM OF SEXUAL CRIME}

1. Identification of the victim and the allegedperpetrator

2. Date and time of examination

3. Date, time and place of an event

4. Details of the sexual abuse (sexual acts, ejaculation, physical violence, drug, alcohol, drug consumption by the victim or perpetrator before the event) 
5. Actions performed by the victim after the incident (change of clothes, bathing, showering, urinating

6. Gynecological and obstetric interview (last period, used contraception, current and past STI, last voluntary sexual contact, previous operations, pregnancies, births and miscarriages)

7. Physical examination - description of the general state, emotional, body injuries (injuries location sketch)

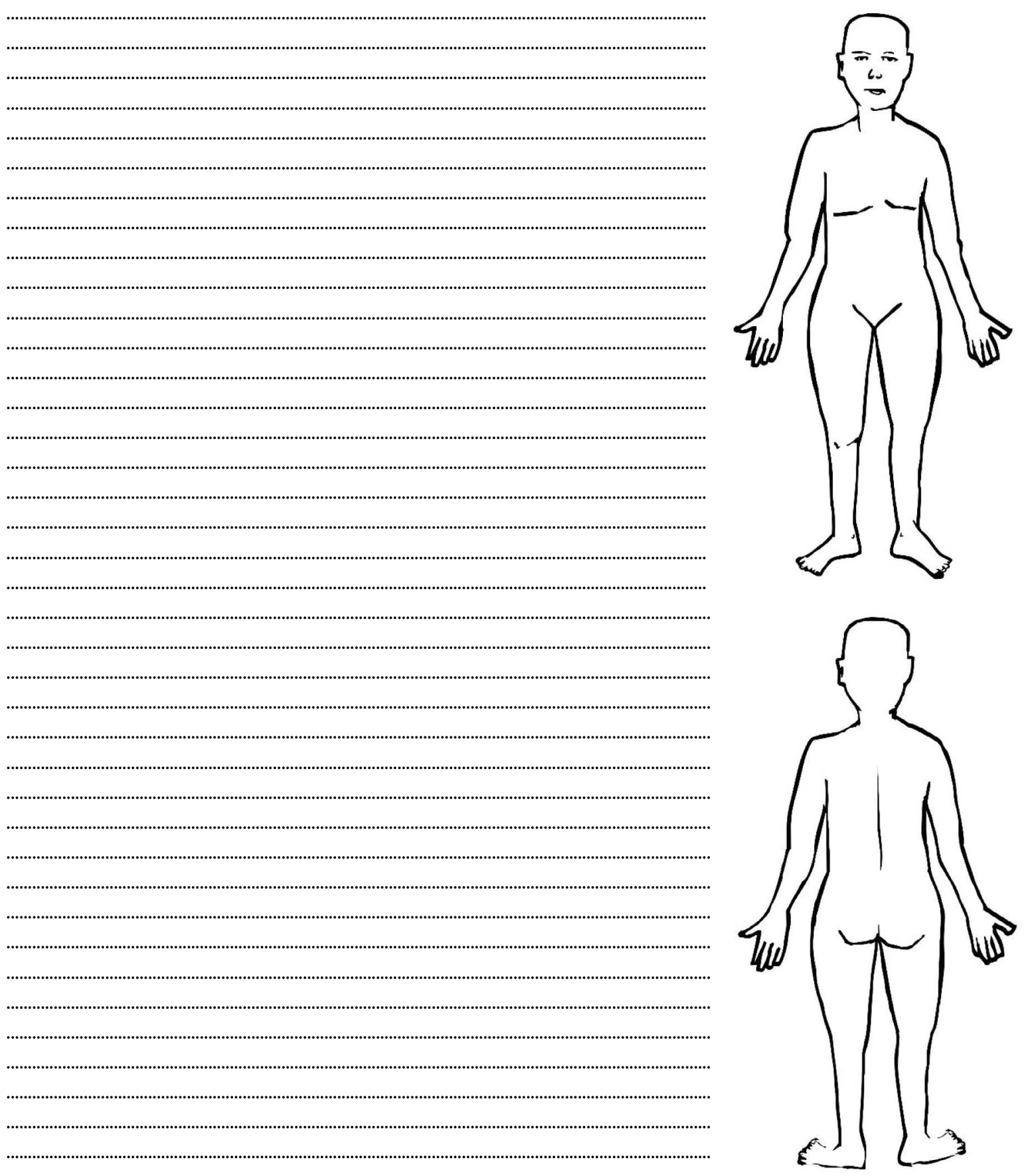


8. Gynecological examination - description of genital injuries (injury localization sketch)

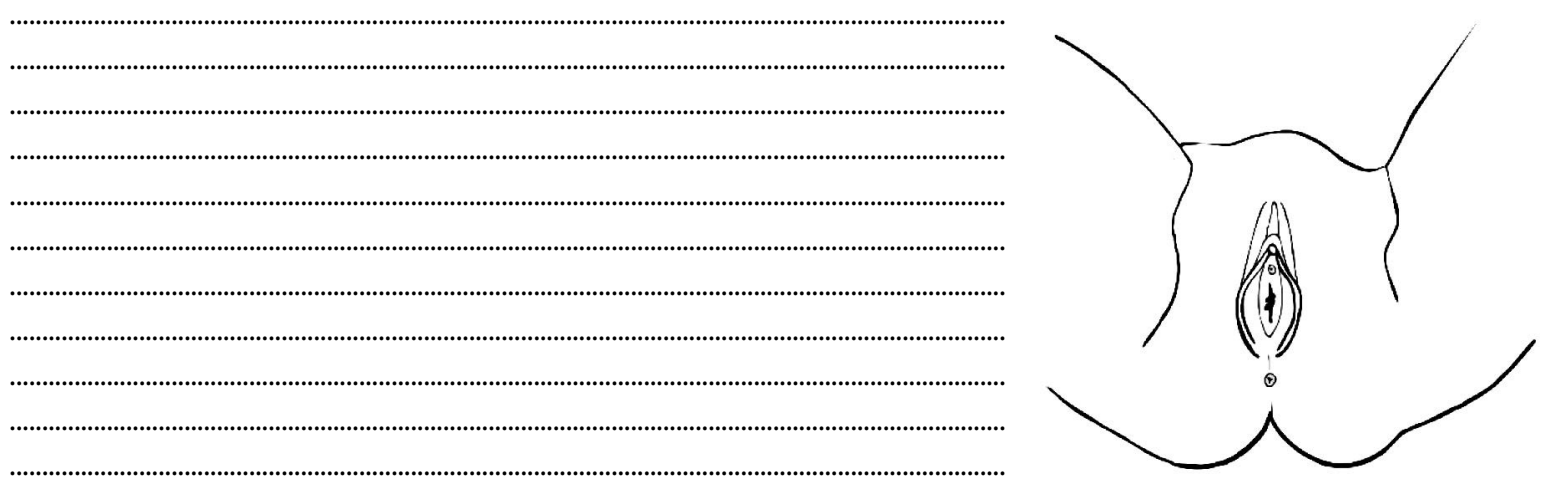

9. Laboratory material collected during a physical and gynecological examination

10. Treatment used (antibiotics, contraceptives, painkillers, sedatives)

11. Medical recommendations (medications, contraceptives, hospitalization, specialist consultations)

I consent to the notification of the law enforcement authorities about the incident Patient's signature

I consent to the examination and activities related to the collection of evidence (including tissue breakdown) and treatment procedures

Patient's signature

I consent to the disclosure of medical documentation to law enforcement authorities

Patient's signature

I declare that I have been informed about the negative consequences of disclosing medical confidentiality Patient's signature 
ANNEX 3. EXAMINATION CARD OF A GIRL - MINOR VICTIM OF SEXUAL CRIME

1. Identification of the victim, statutory representative, and the alleged perpetrator

2. Date and time of examination

3. Date, time and place of an event

4. Details of the sexual abuse (sexual acts, ejaculation, physical violence, drug, alcohol, drug consumption by the victim or perpetrator before the event)

5. Actions performed by the victim after the incident (change of clothes, bathing, showering, urinating

6. Gynecological and obstetric interview (last period, used contraception, current and past STI, last voluntary sexual contact, previous operations, pregnancies, births and miscarriages)

7. Physical examination - description of the general state, emotional, body injuries (injuries location sketch)
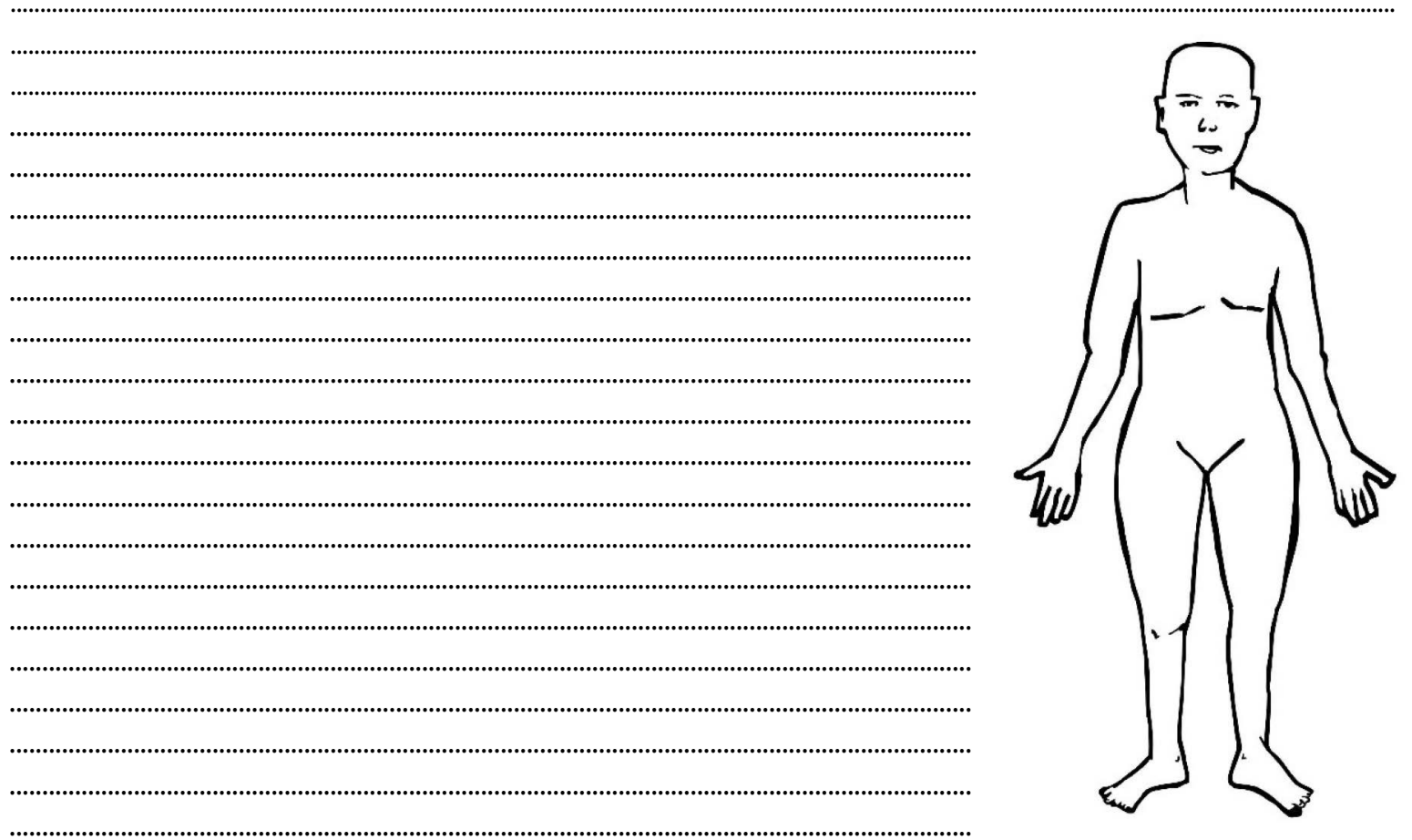

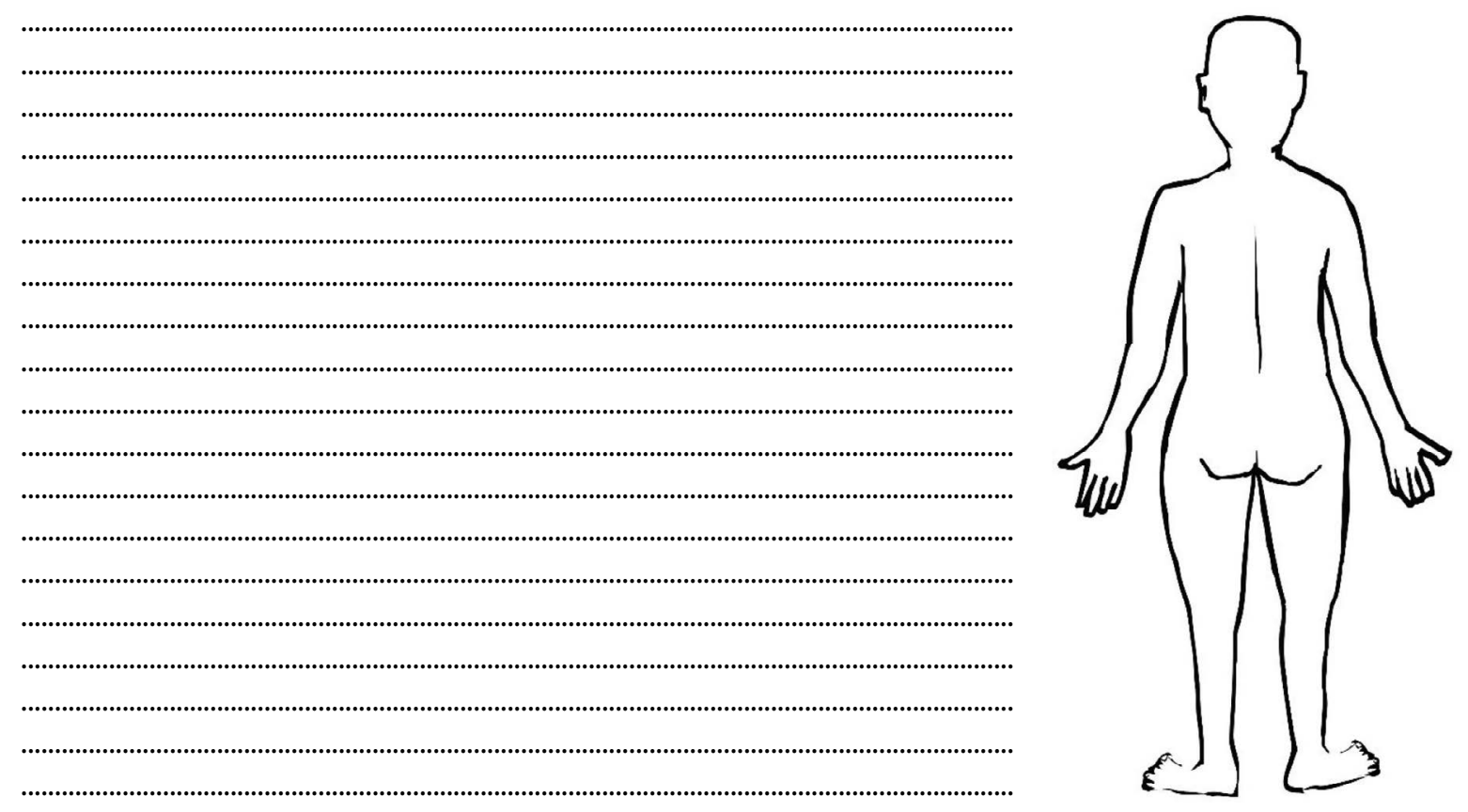

8. Gynecological examinationdescription of genital injuries (injury localization sketch)
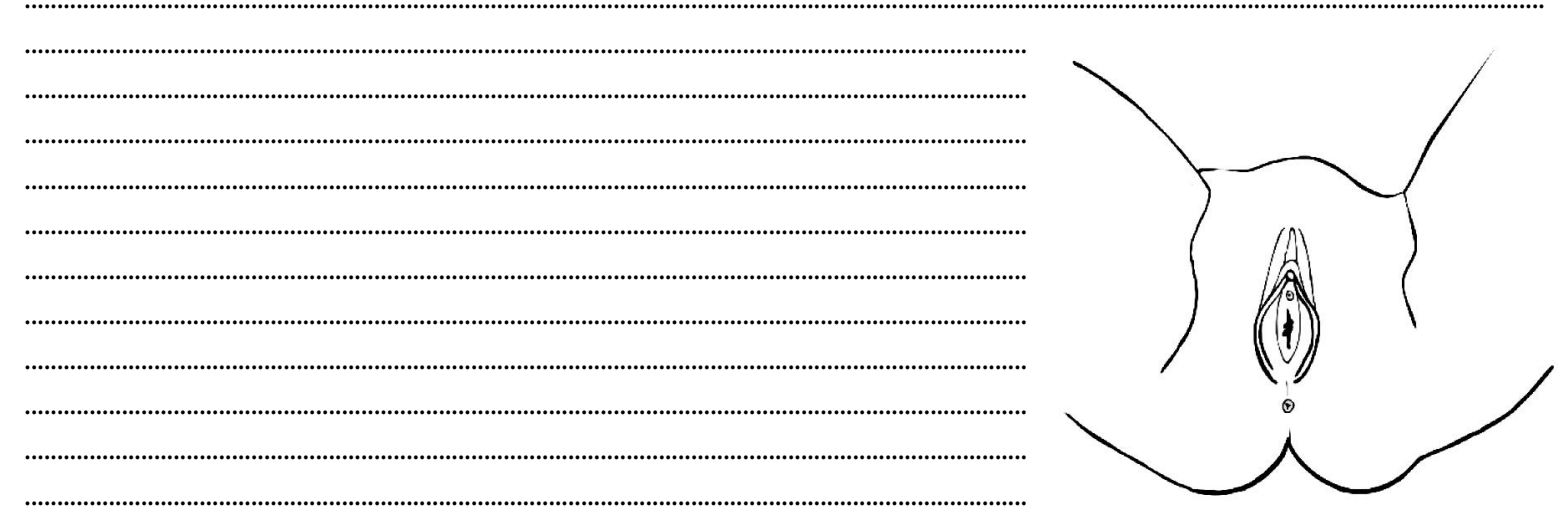

9. Laboratory material collected during a physical and gynecological examination

10. Treatment used (antibiotics, contraceptives, painkillers, sedatives) 
11. Medical recommendations (medications, contraceptives, hospitalization, specialist consultations)

I consent to the notification of the law enforcement authorities about the incident

Patient's signatureStatutory representative's signature

I consent to the examination and activities related to the collection of evidence

(including tissue breakdown) and treatment procedures

Patient's signatureStatutory representative's signature

I consent to the disclosure of medical documentation to law enforcement authorities

Patient's signature

Statutory representative's signature

I declare that I have been informed about the negative consequences of disclosing medical confidentiality Patient's signature

Statutory representative's signature

Stamp and signature of the doctor who was examining

Stamp and signature of the assistant and drawing up the test card

\section{ANNEX 4. EXAMINATION CARD OF A BOY-MINOR VICTIM OF SEXUAL CRIME}

1. Identification of the victim, statutory representative, and the alleged perpetrator

2. Date and time of examination

3. Date, time and place of an event

4. Details of the sexual abuse (sexual acts, ejaculation, physical violence, drug, alcohol, drug consumption by the victim or perpetrator before the event)

5. Actions performed by the victim after the incident (change of clothes, bathing, showering, urinating

6. Gynecological and obstetric interview (current and past STI, last voluntary sexual contact, previousoperations) 
7. Physical examination - description of the general state, emotional, body injuries (injuries location sketch)

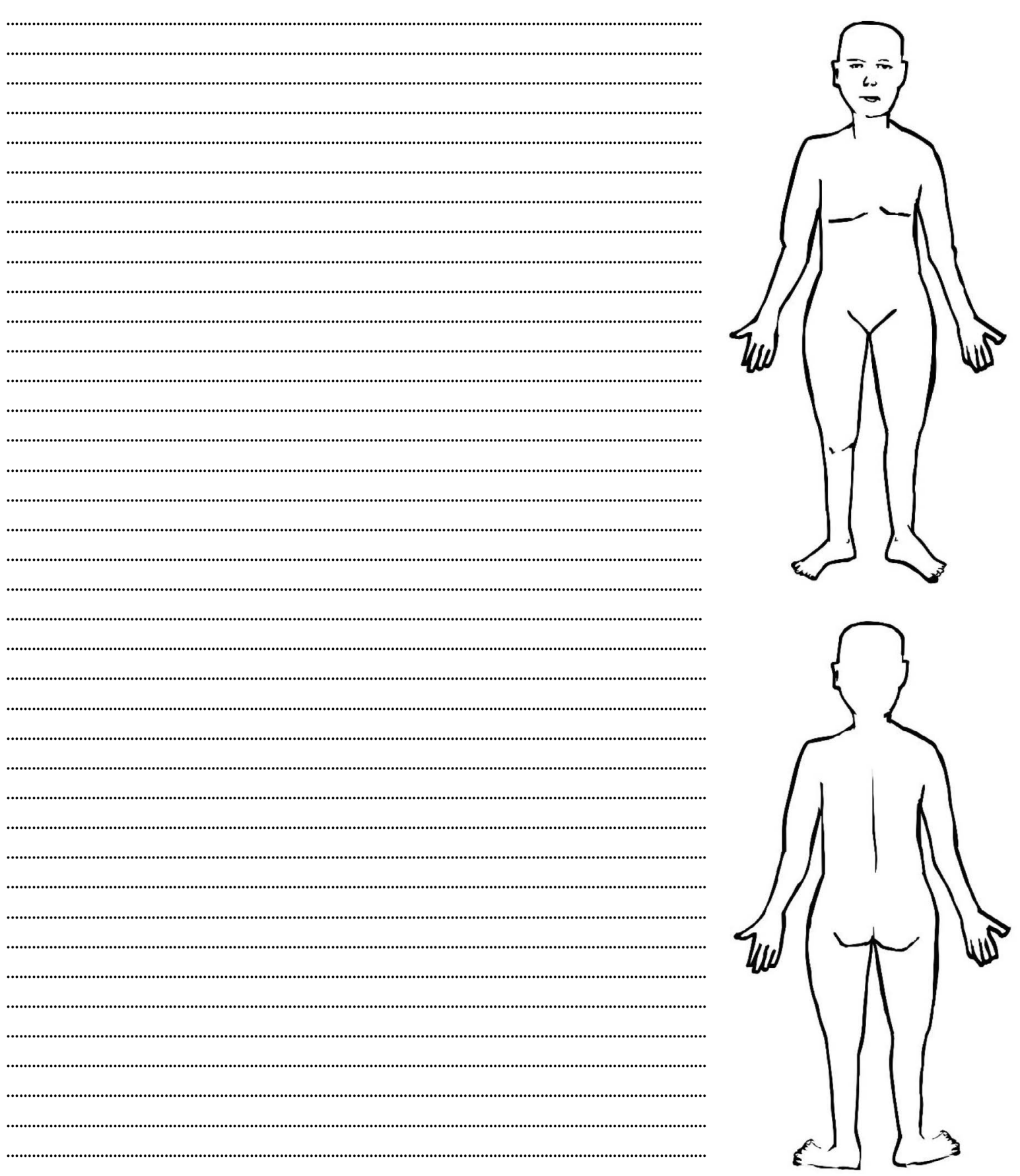

8. Genital examination - description of the injury (sketch of the location of the injury) 
9. Laboratory material collected during a physical and gynecological examination

10. Treatment used (antibiotics, contraceptives, painkillers, sedatives)

11. Medical recommendations (medications, contraceptives, hospitalization, specialist consultations)

I consent to the notification of the law enforcement authorities about the incident Patient's signature Statutory representative's signature

I consent to the examination and activities related to the collection of evidence (including tissue breakdown) and treatment procedures Patient's signature

Statutory representative's signature

I consent to the disclosure of medical documentation to law enforcement authorities Patient's signature

Statutory representative's signature

I declare that I have been informed about the negative consequences of disclosing medical confidentiality Patient's signature

Statutory representative's signature

Stamp and signature of the doctor who was examining and drawing up the test card

Stamp and signature of the assistant 


\section{REFERENCES}

1. World Health Organization. Summary Report. WHO Multi-country Study on Women's Health and Domestic Violence against Women. Initial results on prevalence, health outcomes and women's responses. WHO Library Cataloguing-in-Publication Data, Geneva.; 2005.

2. World Health Organization. Division for the Advancement of Women, Violence against women: a statistical overview, challenges and gaps in data collection and methodology and approaches for overcoming them. Expert group meeting, DAW, ECE and WHO. Geneva, 11-14 April. 2005.

3. United Nations High Commissioner for Refugees. SpringerReference., doi: 10.1007/springerreference_301091.

4. Leder RR, Emans SJ. Sexual Abuse in the Child and Adolescent. W: Pediatric and Adolescent Gynecology. Ed. Emans SJ, Laufer MR, Golgstein DP. 5th Edition. Lippincott Williams and Wilkins, Philadelphia. ; 2005: 939-975.
5. Poirier M. Care of the female adolescent rape victim. Pediatric Emergency Care. 2002; 18(1): 53-59, doi: 10.1097/00006565-200202000-00016.

6. Ustawa z dnia 6 listopada 2008 r. o prawach pacjenta i Rzeczniku Praw Pacjenta (tekst jednolity Dz. U. z 2012 r.poz. 159 z późn. zm.).

7. Ustawa $z$ dnia 5 grudnia 1996 r. o zawodach lekarza i lekarza dentysty (tekst jednolity Dz. U. z 2011 r. Nr 277, poz. 1634 z późn. zm.).

8. Ustawa z dnia 5 grudnia 2008 r. o zapobieganiu oraz zwalczaniu zakażeń i chorób zakaźnych u ludzi (tekst jednolity Dz. U. z 2013 r. poz. 947 z późn. zm.).

9. Ustawa z dnia 6 czerwca 1997 r. kodeks karny (Dz. U. z 1997 r. Nr 88, poz. 553 z późn. zm.).

10. Ustawa z dnia 31 stycznia 1959 r. o cmentarzach i chowaniu zmarłych (tekst jednolity Dz. U. z 2011 r. Nr 118, poz. 687 z późn. zm.).

11. Ustawa z dnia 6 czerwca 1997 r. kodeks postępowania karnego (Dz. U. z 1997 r. Nr 89, poz. 555 z późn. zm.).

12. Ustawa $z$ dnia 29 lipca 2005 r. o przeciwdziałaniu przemocy w rodzinie (Dz. U. Nr 180, poz. 1493 z późn. zm.). 